\title{
Sciendo
}

HOLISTICA Vol 10, Issue 3, 2019, pp. 157-169

\section{Migration and globalization: citizen journalism and immigration policies}

\begin{abstract}
Sorinel lonel, VASILCA, Management Faculty, The Bucharest University of Economic Studies, Bucharest, Romania, Plaza

Romana 6 street sorinvasilca@gmail.com Ella Magdalena, CIUPERC̆̆,

Critical Infrastructures and Cybersecurity Department, National Institute for Research and Development in Informatics, Bucharest, Romania, Bvd Alexandru Averescu 8-10 ellaciuperca@yahoo.com Madlena, NEN, Associate Prof., Department of Foreign Languages, Military Sciences and Management, Military Technical Academy, Bucharest, Romania, George Cosbuc 39-49 madlenanen@yahoo.com
\end{abstract}

\begin{abstract}
International migration represents one of the most important aspects of globalization that contributes to the evolution and transformation of our lives. In 2000, as the United Nations reports showed, approximately 175 million people lived outside their native country for more than 12 months, a number that doubled with respect to the reference year 1975. This means that there are more and more "clashes" between people around the globe, involving greater responsibility for states in integrating the "moving" society. The public perception is continuously impacted by the migration phenomenon in its different aspects, but the effects are highly dependent on the communities' social, cultural and religious pre-determination. In this respect, our paper aims to analyse the reflection of the traditional values of the host society to the individual perceptions on immigration, as expressed in various social media. In our view, in order to maximize the success potential of the public policies adopted by the host states in the field of immigration, these must be tightly correlated with the traditional social values, as observed in the real context, and also closely follow the evolution of these values, as expressed in the digital space. For this purpose, we will compare the social media and real life to show differences and resemblances of the attitudes towards the immigrants who might come in Romania from Middle East.
\end{abstract}

Keywords: migration, social media, labour market, integration, public policy, social reaction.

JEL Classification: F6; J6. 


\section{Introduction}

In recent years, migration represents not only an intensely debated topic, highly present in the media and discussed in various forums from the public space, but also a very rich and innovative research field for the scientific literature. While migration is not a new phenomenon, but rather a very old one - perhaps the most well-known migration example is the invasion of barbarian populations in Europe between III-XI centuries - the research on this topic is experiencing an interesting revival.

Even if migration is almost unanimously considered to bring along numerous benefits, both from the perspective of the people involved in migration and also the one of the host countries, this phenomenon may create various challenges, especially in the area of national and international security. The migration of a mass of people who do not necessarily share the same values either cultural, religious or ideological- as the ones that are prevalent in the host country they travel to, has the potential to affect the social equilibrium of the latter, thus threatening its cultural identity, fundamental values, social security and even public safety. The most severe impact can be triggered by different factors, such as the dimension of the phenomenon (number of people involved), cultural and religious traits of the host societies, and the degree of flexibility and openness (generally linked to the degree of education) of the migrants. Worst observed cases include violent confrontations between the migrants and the host population or the public safety institution.

\section{Security and Migration}

The concept of migration is defined as the movement of population across borders, from one nation state to the other or from one society to the other (Treibel, 1990, 21). At their turn, experts such as Barry Buzan (1993) or Thomas Faist (2000) consider that a people's movement may be labelled as migration when the following 3 criteria are met:

- It involves the permanent or a clearly defined periodof changing of residence;

- It must overcome administrative boundaries;

- It has to happen over aperiod of time deemed significant.

Migrations produce effects both in the destination countries and the countries of origin.

The following effects can be noted in the destination countries: 
- Economic effects: in the case of a pronounced deficit of the workforce in the destination country, either generalized or just localized to specific areas, it can be compensated by immigrants. Instead, a situation that inevitably stimulates the phenomenon of rejection among the host population is the one where migrants compete against local workforce, the latter either native or originating from previous migration waves. Integration situations with beneficial effects on both sides are those where the immigrants are targeting those areas of the labour market generally shunned by natives, especially those requiring less training or strict specialization. Situations in which the level of education and experience of immigrants can compete with the population of the host country are relatively rare, and in these cases they will benefit from a privileged status.

- Demographic effects: in terms of immediate impact, the immigration phenomenon brings changes to the distribution of the population of the host country from multiple perspectives, i.e. ethnic, religious, age

- Social effects: the rejection and marginalization phenomena towards the immigrants can lead to a natural reaction of these ones to only populate neighbourhoods with specific issues or peripheral areas, where language and cultural barriers do only perpetuate, therefore perpetuating the integration problems. Immigrants' congregation within specific geographic perimeters does often result in marginalization and fosters crime, thus limiting the chances of integration. A first step towards combating this phenomenon is the adoption of dedicated policies for integration, such as cultural, linguistic, educational etc.

Addressing migration in the literature was performed under different security studies paradigms, such as: liberal, realist, neo-realist and human security paradigm. In this context, we note that a security paradigm is a theory which consist in the existence of a framework, and that includes axioms, assumptions and theories related to the international security system.

The field of migration was approached in international literature in a contradictory manner, labelled by Hollifield (1992) as the liberal paradox. This paradox is derived from the assumptions that:

1. Individual liberty and rationality are some very important features of human beings, and hence the freedom of movement of people, goods, capital and services must be respected. Any restriction of this freedom is considered to be associated with authoritarian governance;

2. In the virtue of national sovereignty, a state is entitled to control its borders and keep at least one sort of evidence of its people. In this view, migrants 
are considered to be rational people, who chose to migrate after a well-informed decision.

The realistic paradigm's first assumption is that actions of the states are motivated by their interests and not by ideals, states interpreting all the situations rationally, acting in a way that will increase their power and their security. While the realistic paradigm is considered to be a highly pessimistic one, the competition for resources is never questioned, power being the key to understand international behaviour of states and their motivations. Considering the realist and neorealist paradigms, for a state to behave independently, it should rely upon a numerous population, consistent natural resources and a vast territory. From this perspective, migration is changing its colour - people are determined to go from one place to another by higher decisions that have no consideration for their individual interest, but are rather take into increase one state's power and/or influence.

Basically, the concept of security might apply to anything and everything. Concepts like regional security, national security, group security, individual security had been approached by many specialists like Barry Buzan. We witness against two different sides having the same purpose: placing a limit to the discussions on this topic. The first one represents a state point of view, where security must refer especially to military threats. On the other side, per the liberal ideology, that extending of the meaning of security to the individual, ecological and economic security might be the key to confront the real problems faced by every human being: sickness, diseases or even poorness (Robinson Paul, 2010, 194). While globalization is about the freedom of movement, security of states is about raising wall before anyone who may compete for the same resources.

In the last 25 years, many academic voices have considered that international security should be addressed based on the human security paradigm, considering it as the only one capable to provide long term solutions to the conflict generated problems.

The concept of human security was firstly mentioned by United Nations Human Development Report in 1993 and it was soon applied by Western countries as Norway and Canada. The most important assumption of this theory is that individuals and not states should be in the center of any policy and that the security of all people is interconnected. Otherwise authoritarian governance, that produces injustice and poverty, will lead to terrorism, migration, and many other threats to international security.

Therefore, human security was defined by Commission on Human Security $(2003,4)$ : “...to protect the vital core of all human lives in ways that enhance 
human freedoms and human fulfilment. Human security means protecting fundamental freedoms - freedoms that are the essence of life. It means protecting people from critical (severe) and pervasive (widespread) threats and situations. It means using processes that build on people's strengths and aspirations. It means creating political, social, environmental, economic, military and cultural systems that together give people the building blocks of survival, livelihood and dignity." (http://www.un.org/humansecurity/sites/www.un.org.humansecurity/files/hum an_security_in_theory_and_practice_english.pdf)

\section{Migrants' Rights and Host Population's Attitude}

In international business we most often talk about country-based cultures, but cultures also develop around professions, organizations, religions, and so on (Gunter K Stahl, Martha L Maznevski, Andreas Voigt, and, Karsten Jonsen Unraveling the effects of cultural diversity in teams: A meta-analysis of research on multicultural work groups.)

Furthermore, because of historical combinations, increased immigration, or temporary flows of people across borders, most countries include multiple ethnic cultures, and many ethnic or religious cultures span country boundaries (Leung, Bhagat, Buchan, Erez, \&Gibson, 2005; Tung, 2008).

Research of the migration phenomenon generally reveals two radically divergent perceptions:

- The one of the host population, who often believe the migrants represent only a surplus of people, responsible for the lack of jobs and salary depreciation, and

- The migrants' one, that often find their expectations are not met, themselves marginalized, discriminated, pushed into poverty.

All humanitarian migration crisis on record illustrate this opposition. For example, during the late '70s and also in the early ' 90 s, the situation of Palestinians in Lebanon meant too many people taking shelter in refugee camps, which lead to a huge destabilization of the host country. In both periods, the refugees' presence resulted in sparking a civil war and eventually triggered the intervention of external institutions and states (Robinson, p. 128)

From a different perspective, looking to migration through the total isolationist lens might have negative consequences. Seeing all migrants as threats 
to national security may encourage the rejection of the host society that may adopt a discriminatory and even hostile attitude towards these people.

The migrants' position may be regarded from the perspective of many variables such as (Sude et al., 2015): the reasons they left their origin country, the ethnical and religious differences between host and origin country, the number of refugees, their legal status, the main non-governmental organisations involved, the policies on migration in host countries, the rights and resources dedicated to refugees, their access to jobs, education, the external contacts of refugees, the deviance history of refugees, the presence of armed people, the political organization of refugees camps.

From the perspective of migrants seen as consumers of public services, satisfaction or in-satisfaction regarding the conditions they are offered by the receiving country are often subjective in nature. As considered by A. Grigorescu (2008), they "...have both needs and desires, and it is very difficult to make a precise distinction between them. From this point of view, those being aware of their needs and considering anything above this level as desire have a realistic perception of the way their needs are satisfied. The consumers that mix the needs with their desires have a distorted perception and a low degree of satisfaction. The public service has the role to serve and satisfy the public need. This can be identical with the individual need, or it can often be below its level, which is, as we have shown, very difficult to distinguish from desire." That is why the public administration of the recipient countries, has to consider the migration phenomenon as a fact, and to take all the provisions to satisfy first the basic needs, and later on to address the other needs of the incoming people, but at the same time not to induce a dissatisfaction or even a rejection wave among the receiving society citizens.

While trying to curb the number of migrants in European states, there is a great interest in implementing measures that should facilitate the integration of migrants, mainly in the field of preserving identity, giving rights and responsibilities similar to those of the European citizens, observing the democratic values and the high involvement of migrants in all the fields of European society.

Public and local authorities should make use of a systematic, scientific approach to determine the expectations of the migrants that can be considered as consumers of public policies. These expectations should be correlated with a number of factors, such as the reason for emigrating, education level, work skills, experience, age, gender, etc. in order to establish the acceptable level of needs that have to be addressed. Grigorescu \& Bob (2011) evoke such a method, in that "the method of multiple discriminator is successfully used in the analysis of 
customer segmentation, consumer behaviour, market positioning/segmentation, focus groups and knowledge management, projects and risk management, destination management and marketing, competitive advantage, strategic differences etc."

European Council adopted in 2004 some fundamental principles in order to promote the European common vision, which underlined the fact that integration is a long and dynamic process, addressed both towards migrants and host population; with the observation of the fundamental values and legislation of European Union; looking to learn about the language of host country and its history and political organization; employment as a mean to prove their utility in society; education; access to institutions, services and resources; frequent contacts with majority, free practicing of religion, involving in the democratic process and also in their integration programmes; involving of the civil society, clear objectives and indicators.

\section{Methodology: Romanian case study, as reflected in the social media}

While every policy on migration assumes integration as a main objective, one of the major obstacles to attain it is the host population perception of those new social groups. Researches that tried to identify tolerance of people are not an easy thing to do because of the many variables that can interfere. Still, the European Commission delivered an Euro barometer which is showing significant differences across some contradictory figures: the large majority of European countries are against receiving migrants from outside EU, while Sweden has a positive attitude towards migrants. Romania case reveal a divided public opinion: $48 \%$ of Romanians have also a positive attitude, meanwhile $34 \%$ of them are against it.

With a preponderantly positive opinion in Romania regarding the acceptation of refugees, our hypothesis is that social media should reflect a similar distribution. The numbers of posts provide an indication on the quantitative reflection of the phenomenon in the social media, the analysis of their content helps provides a qualitative assessment of the attitude towards the arrival of refugees in Romania.

For this purpose, we monitored the largest forum of Romania softpedia.com - from September 2015 to January 2016, but also dedicated discussion forums such as www.nationalisti.ro. Social media reflect another (i) 
reality: while there are a few positive comments regarding refugees, most of the post reflects negative feelings and beliefs of people towards this subject. Our objective was to identify the main themes of polemics, as they result from internet. People are not revealing their real identity but use nicknames instead (ex: vampera, casadivino, engineer_xxl).

The main themes we identified within the negative comments are beliefs regarding migrants, many types of fears (economic, security, world conspiracy) or about people and institutions considered to be responsible for this situation, as they are exemplified below.

The majority of the posts reflect a negative attitude towards the migrants that can be tracked to different categories of motivations:

\section{-Impact on the labour market}

The perceived impact on the labor market does not necessarily reflect concern, but rather beliefs that both the qualification and the professional level of the migrants are not likely to present a threat to the segments in which the authors of the posts operate.

- "Migrants? Of course, they will work - a bomb by day!"(http://forum.softpedia.com/topic/1029780-romania-si-imigrantii-ce-vorveni/page_st__18.)

- "Well... they have a job in which they excel, they are social assisted by profession. Besides this, they have some interesting hobbies, terrorism being the favorite one. It is followed by conquering places by uncontrolled breeding and imposing their own religion." (http://forum.softpedia.com/topic/1029780romania-si-imigrantii-ce-vor-veni/page_st__54.)

- "As for me, they can come because we need hard working persons. But without any mosques! I don't feel like seeing fanatics in Romania. We have enough already: the Pentecostals, the Witnesses of Jehovah and others alike."(http://forum.softpedia.com/topic/1029780-romania-si-imigrantii-ce-vorveni/page_st_18.)

Other people are trying to identify a middle way and they show a conditioned tolerance to migrants:

- Threats perceived by the host population

- Economic and social impact

Developing and implementing social assistance programs for disadvantaged groups in the host society could diminish the negative perception 
expressed by the authors of posts regarding the social impact of receiving migrants.

- "This is the only thing left for us to do! We do have unequipped hospitals, suffering elders, children suffering of famine..." (http://epochtimescromania.com/news/romania-va-infiinta-trei-noi-centre-de-migrație-241728)

- "Why don't you make a center for homeless people. You should be ashamed... You have no idea what cars refugees have, only BMW and Mercedes. Give money to Romanians first and then to the others!" ( http://epochtimescromania.com/news/romania-va-infiinta-trei-noi-centre-de-migrație-241728 )

\section{- Security fears}

According to the spring 2016 Eurobarometer, conducted during the period May 21st to 31st, cited by Ziarul Financiar "terrorism is the second most important source of concern for EU citizens, being indicated as a very important issue facing the EU by $39 \%$ of respondents, up $14 \%$ from the previous survey, which was conducted at the time of the attacks in Paris in November "(http://www.zf.ro/business-international/eurobarometru-terorismul-principalaproblema-cu-care-se-confrunta-ue-in-opinia-romanilor-15545495 )

We want to point out that in Romania, terrorism was mentioned by $49 \%$ of respondents as one of the most important issues facing the EU, a percentage exceeded only by that registered in Ireland and Cyprus (50\%). This may be considered surprising in light of the fact that Romania has not faced situations of conflict or acts of terrorism, as happened in the recent history of the two countries that registered the highest percentage on this issue.

- "We don't need anarchy or any others crimes and Romanian people pay for it!"(http://nationalisti.ro/2016/01/opriti-marea-migrație-a-refugiatilormusulmani-in-romania/.)

- "They are just like the gipsy beggars! They swear to you the very moment you give them clothes and food. Wait and see when you will install them in Europe! They will use Molotov cocktails just like they do in their own country."(http://forum.softpedia.com/topic/1029780-romania-si-imigrantii-cevor-veni/page_st__72.)

- "Those who commits rape and those who steal should be emasculated the same way pigs are ..." (http://nationalisti.ro/2016/01/opriti-marea-migrație-arefugiatilor-musulmani-in-romania/.) 
- "The only mistake we can make is to accept them and shortly we will be like Kovoso, but Americans are going to be too busy to care about the rest of the world."(http://nationalisti.ro/2016/01/opriti-marea-migrație-a-refugiatilormusulmani-in-romania/.)

\section{Opinions reflecting global conspiracy}

Global conspiracy and the involvement of the major world powers are considered to be decisive for the evolution of migration phenomenon.

- "Stop soviet secret service actions on Romania's land!..."(http://alternativenews.ro/2016/09/felicitari-putin-bravo-rusiadeclaratia-tarului-care-a-incantat-intreaga -europa.html.)

- "Victoria Nuland is coming from USA exactly at this moment to talk about Basarabia which is threatened by pro-Putin forces, but in fact every situation of the countries around Black Sea looks like before a major war."(http://nationalisti.ro/2016/01/opriti-marea-migrație-a-refugiatilormusulmani-in-romania/.)

- "They begin to come.... These invaders... I think everything is planned... one step at a time, so that we don't see it coming".(http://nationalisti.ro/2016/01/opriti-marea-migrație-a-refugiatilormusulmani-in-romania/.)

\section{People and institutions held accountable for the situation}

Government stands out as a decision factor in solving the problem of migration.

- "Bring many migrants and punish the Romanians! Let them suffer of famine and lack of medicines, you irresponsible government!" (http://nationalisti.ro/2016/01/opriti-marea-migrație-a-refugiatilor-musulmaniin-romania/)

- "Of course we don't need them. Did our government understand that they might be dangerous and will they send them back? On media they said that they are not yet decided if they will send them back to Serbia or if they will host them in refugee camps." (http://nationalisti.ro/2016/01/opriti-marea-migrație-arefugiatilor-musulmani-in-romania/)

- "Orban, for your policies regarding refugees issue, I salute you! You are a true leader! Step by step we will hold down Arabic 
invasion!"(http://www.expunere.com/premierul-ungariei-viktor-orban-ungariaeste-bine-protejata-de-migrație-sunt-necesare-pregatiri-la-granita-curomania.html)

- “Good job! We are looking towards a country who`s surface is a quarter of Romania. With great leader who are able to solve migration issue without being scared by EU's institutions. The people matters to him more than rich guys who controls everything!" (http://www.expunere.com/premierul-ungariei-viktororban-ungaria-este-bine-protejata-de-migrație-sunt-necesare-pregatiri-lagranita-cu-romania.html)

\section{Positive attitude}

There are a number of people trying to find a middle way and show a conditional tolerance towards the migrants. This kind of attitude can be a starting point for establishing an acceptance framework for situations resulting from the migrants' integration.

- "Whether they come to work or to beg, if you do not integrate them and you do not teach them your language they will be only one more burden and a source of deviance. No matter how hard they are able to work, they need to learn the language and for this it is necessary to have an infrastructure, someone to take care of this people. And then, the other problems that must be addressed are accommodation, and places for prayers... a lot of things that should be anticipated and not solved along the way." (http://forum.softpedia.com/topic/1029780-romania-si-imigrantii-ce-vor-veni/)

- "I am wondering whether those who totally refuse to help migrants have ever experienced suffering, if they were ever hungry. If they ever lack a coat or a pair of shoes. I supposed they didn't otherwise I cannot imagine how could someone be so cold and insensitive to others' sufferings." (http://forum.softpedia.com/topic/1029780-romania-si-imigrantii-ce-vorveni/page_st__36.)

- "I am not insensitive to other problems or when someone asks me for help, no matter its ethnic origin, religion or skin colour. If you do not want to help it's your own business, but to turn this into propaganda is too much for me! I personally know Muslims and they are not terrorists. My colleagues are very nice persons with families, jobs, children and problems like I have. Should I refuse to talk to her because she is a Muslim immigrant from 
Iraq?"(http://forum.softpedia.com/topic/1029780-romania-si-imigrantii-ce-vorveni/page_st__54.).

\section{Conclusion}

It is reasonable to consider that the migration phenomenon overlapped with a number of humanitarian crises, which determined an important deal of concern in the public space and an important pressure at the level of receiving countries decision makers. While statistical methods can be used to map the migrants' expectations in order to establish the basis of their needs to address on a priority basis, we consider the biggest challenge of the authorities of the receiving countries is the host population rejection of the newcomers. The analysis of the positive outcomes of migration may result in solutions for the host countries that have already been adopted and confirmed in the highly-developed states. Efficient migrants' integration in the work field may solve the lack of qualified workers and by extending this integration to the whole society; it may even solve the ageing trend of the population. But for all these to happen, it is of the highest importance to determine at least some of the people, in minority but very vocal, to change their adverse mind set. We consider that understanding from a quantitative and qualitative point of view the negative position of some citizens and their motivations is the first step to be taken by the governments in designing efficient public policies to cope with the migration phenomenon.

\section{References}

[1] Faist, Th., (2000).The Volume and Dynamics of International Migration and Transnational Social Spaces. Oxford: Oxford University Press

[2] Grigorescu, A., (2008). Quality and Customer Satisfaction in Public Services. RevistaAmfiteatru Economic, Special 2, p.130-135, ISSN 1582 - 9146

[3] Grigorescu, A. \& Bob, C. A., (2011). Discriminant Analysis For The Abilities Of Public Marketing Specialists. Romanian Journal of Economic Forecasting, Volume 14, Issue 4,p.68-78

[4] Gunter K Stahl, Martha L Maznevski, Andreas Voigt, and, Karsten Jonsen Unraveling the effects of cultural diversity in teams: A meta-analysis of research on multicultural work groups. Journal of International Business Studies, Nov 2009

[5] Hollifield, J. F., 1992. Immigrants, Markets and States: The Political Economy of Postwar Europe. Cambridge, Mass.: Harvard University Press.

[6] Leung, K., Bhagat, R. S., Buchan, N. R., Erez, M., \& Gibson, C. B.2005. Culture and international business: Recent advances and their implications for future research. Journal of International Business Studies

[7] Robinson, P., 2010. Dicționar de Securitate internațională. CA Publishing, Cluj Napoca

[8] Sude, B., Stebbins, D. and Weilant, S., 2015. Lessening the Risk of Radicalization. Rand

Corporation.

Available at: 
http://www.rand.org/content/dam/rand/pubs/perspectives/PE100/PE166/RAN D_PE166.pdf [Accessed 11thJanuary 2016]

[9] Treibel, Annette, 1990. Migration in modern Gessellschaften. SozialeFolgen von Einwanderung, Gastarbeit und Flucht. Juventa, Munchen

[10] Tserng, H. P., Lee, M.H., Hsieh, S.H. and Liu, H.L., 2016, The measurement factor of employee participation for Knowledge Management System in engineering consulting firms, Journal of Civil Engineering and Management 22(2): 157-167. https://doi.org/10.3846/13923730.2014.897963

[11] Vlăduțescu, Ș., 2015. How Does Emerge the Message in Social World. In Sandu, A; Frunza, A; Ciulei, T; et al., 6th Lumen International Conference on Rethinking Social Action Core Values (pp. 1385-1389), Iasi, Romania.

[12] Vieira, D. 2013. Inter organizational learning in the Brazilian bioethanol industry, in Management Knowledge and Learning International Conference, 19-21 June 2013, Zadar, Croatia.

[13] Valencia, J. C. N., Valle, R. S., Jiménez, D. J. 2010. Organizational culture as determinant of product innovation, European Journal of Innovation Management 13(4): 466-480. https://doi.org/10.1108/14601061011086294

[14] Weaver, O.,Buzan, B., Kelstrup, M. and Lemaitre, P., 1993. Identity, Migration and the New Security Agenda in Europe. New York: St Martin Press

[15] Wang, C. L., Rafiq, M. 2009. Organizational diversity and shared vision: resolving the paradox of exploratory and exploitative learning, European Journal of Innovation Management 12(1): 86-101. https://doi.org/10.1108/14601060910928184

[16] Zavadskas, E. K.,Kaklauskas, A. and Banaitis, A. 2010. Real estate's knowledge and device-based decision support system, International Journal of Strategic Property Management 14(3): 271-282. https://doi.org/10.3846/ijspm.2010.20 